\title{
静止充虽層内における层熱* 一一層内温度分布におよばす輻射の影雾——
}

满

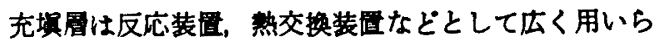
れている。このよらな装圈を云熱的な面から検討する場 合，伝熱量ととすに届内温度分布をす梌討することが重 要である。従来静止充埙屏内における层熱山，伝等およ び輻射による各云熱抵抗を総括したいわゆる有効熱云年 度を用いて検討されている垛合が多い。このような有効

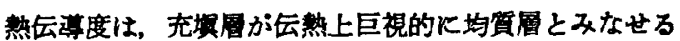
胃径が大きい場合あるい恃充填粒子径が小さい場合には 有用と思われるが，輻射の寄与が大きく，層径が小さい 場合あるいは充堚粒子径が大きい場合には，㬏射伝熱が 粒子間空隚を通して行なれれるといら性質をるつため塈 の影籍が顕著になり，云熱量むさることながら啳内温度 分布に関しては有効熱层導度では説明できないよらな場 合すあると考えられる。前述のよ5に充埧周内の云熱に おいては伝裆量と温度分布の両者を娭討しなければなら ないか，本研究ではます輻射が充塓層内温度分布にいか 飞影需するかを検討するため，静止充填屏（ガス，平行平 板系)をとりあげ，従来の有好熱云導度より求めた雷内

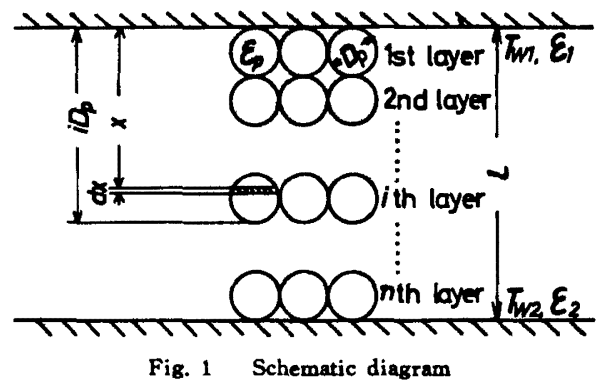

- <Heat Transfer in Static Packed Beds - The Effects of Radiation on the Temperature Distributions- $->$ Received on September 28, 1970

化学工学協会第 4 回仗平大会（蚛，昭和 45 年 10 月）にて研究 觜竞

** Makoto Nishimura, Sachio Sugiyama (Dept. of Chem. Eng., Nagoya Univ, Nagoyo)

*** Yoahihiro Inaba (日本油脂 (株) Nippon Oils and Fat: Co., Nagoya, Japan)

**** Masanobu Hasatani (伎策大学工学部 Faculty of Engineering, Gifu Univ, Kagamigahara)

\author{
西 村誠** ・稲 菜 由 大*** \\ 架谷昌信****. 杉山幸男** \\ 名古屋大学工学部 化学工学科**
}

温度分布と新たに輻射に咸して頪の影䇾を考虑したモデ ルより求めた層内温度分布とをカオリン球を用いた実鍳 結果と対応させて比較検討した。さらに輻射の奇与，有 効熱层尊度および本モデルの有用性などについて考察を 行なった。

\section{1. 基灌式と数值解法}

ここでは㕣内温度分布に関して，徒来の有奻第云導度 を用いた場合および新たに輻射に塈の影霓を考虑したも デルを用いた場合についてそれぞれ基礎式を道き，それ らを数值的火解く。

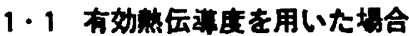

Fig. 1 示す上らな静止充填䈐（平行平板系）を考え る。自然対流はないとし，熱流は1次元とするとこの 場合の基磷式は,

$$
\frac{d}{d x}\left(-k_{e}(T) \frac{d T}{d x}\right)=0
$$

ここに $k_{s}(T)$ は有奻熱伝導度であり，後述の上うに 温度の関数である。

境界条件は，

$$
\left.\begin{array}{l}
x=0 ; \quad T=T_{w 1} \\
x=L ; T=T_{v 22}
\end{array}\right\}
$$

Eq.（1）を境界条件 Eq.(2)のむとで栍分を行な5と。

$$
x=L \frac{\int_{T_{01}}^{T} k_{0}(T) d T}{\int_{T=1}^{T+1} k_{0}(T) d T}
$$

となる。

$k_{e}(T)$ か温度 $T$ に対して単調な変化をするのて， $T_{w 1} \sim T_{w 2}$ 間を $m$ 等分 ᄂ, $T_{i}=T_{w 01}-\left(T_{w 1}-T_{w 2}\right) i / m$ とおき，Eq.(3)を梯形則にて数値䄶分すると。

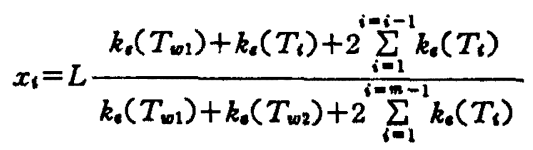

となる。Eq.(4)上り病内温度分布が求まる。

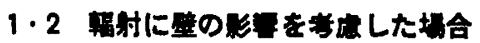

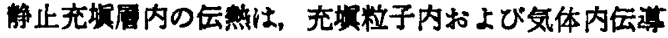


ならびに空隌間峝射の直列あるいは並列の組合わせによ って行なわれる。ここでは充塓粒子内および気体内伝導 を一括して見かけ熱云導度で表わせると考光，この伝導 熱流束と空傹間楅射による需射熱流束とが並列であると する。1・1 と同様に 自然対流がない平行平板系を考え ろと, 基礎式恃,

$$
\frac{d}{d x}\left(-k_{a}(T) \frac{d T}{d x}+F(x)\right)=0
$$

ここに $k_{a}(T)$ は充媜粒子内および 気体内伝導に関す る見かけ熱云導度であり， $F(x)$ は幅射熱流束である。 なお境界条件は $1 \cdot 1$ 之同様に Eq.(2)である。

楅射熱流束 $F(x)$ を式化するため，充虽層内の各層に Radiosity の考えを取り入れる。いま，Fig. 2 に示すよ

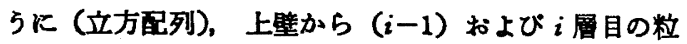

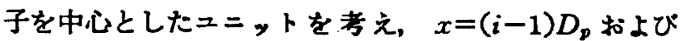
$x=i D_{p}$ 面における正方向および負方向の Radiosity それぞれ $R_{2 t-2,} R_{24}$ および $R_{2 t-1}, R_{2 t+1}$ とする。ガス雷 射がないとすればおのおののRの間には近似的につぎの よらな関俰がある。

$$
\begin{aligned}
R_{2 i}= & \phi_{1} R_{2 i-2}+\phi_{1}\left\{\frac{\pi \varepsilon_{p} \sigma}{D_{p}} \int_{(i-1 / 2) D_{p}}^{(D,} T^{4} d x\right. \\
& \left.+\phi_{2}\left(1-\varepsilon_{p}\right) R_{2 i+1}\right\} \\
R_{2 i-1}= & \phi_{1} R_{2 i+1}+\phi_{2}\left\{\frac{\pi \varepsilon_{p} \sigma}{D_{p}} \int_{(1-1) D_{p}}^{(1-1 / 2) D_{p}} T^{4} d x\right. \\
& \left.+\phi_{3}\left(1-\varepsilon_{p}\right) R_{2 i-2}\right\} \\
R_{0}= & \left(1-\varepsilon_{1}\right) R_{1}+\varepsilon_{1} \sigma T_{w 1}^{4} \quad(i=1 \sim n) \\
R_{2 n+1}= & \left(1-\varepsilon_{2}\right) R_{2 n}+\varepsilon_{2} \sigma T_{v 2}^{4}
\end{aligned}
$$

ここに, $\phi_{1}$ は $x=(i-1) D_{p}$ 面 $\rightleftarrows x=i D_{p}$ 面の角関 係, $\phi_{2}$ は粒子半球面 $S \longrightarrow x=(i-1) D_{\text {, 面あるいは粒 }}$ 子半球面 $S^{v} \longrightarrow x=i D_{p}$ 面の角蔺俰， $\phi_{3}$ は $x=(i-1)$ $D_{p}$ 面 $\longrightarrow S$ あるいは $x=i D_{p}$ 面 $\longrightarrow S^{\prime}$ の角成㐿を表 わす。また， $x=(i-1 / 2) D_{p}$ 面および $x=i D_{p}$ 面におけ る $F$ をそれぞれ $F\left\{(i-1 / 2) D_{p}\right\}, F\left\{i D_{p}\right\}$ とすると， $F$ と $R$ の間の関係は,

$$
\left.\begin{array}{ll}
F\left\{\left(i-\frac{1}{2}\right) D_{p}\right\}=\phi_{4}\left(R_{2 i-2}-R_{2 i+1}\right), & i=1 \sim n \\
F\left\{i D_{p}\right\}=R_{2 i}-R_{2 i+1}, & i=0 \sim n
\end{array}\right\}
$$

となる。ここに, $\phi_{4}$ は $x=(i-1) D_{\text {D }}$ 面 $\longrightarrow x=(i-1 / 2)$ $D_{p}$ 面あるいは $x=i D_{p}$ 面 $\longrightarrow x=(i-1 / 2) D_{p}$ 面の角闺 係を表わす。

つぎに, $F\{x\}$ を $F\left\{(i-1) D_{p}\right\}, F\left\{(i-1 / 2) D_{p}\right\}$ およ び $F\left\{i D_{p}\right\}$ を用いて近似的に直線内㨉すると，

$$
\begin{aligned}
& (i-1) D_{p} \leq x<\left(i-\frac{1}{2}\right) D_{p} ; \\
& F\{x\}=\frac{2\left[F\left\{\left(i-\frac{1}{2}\right) D_{p}\right\}-F\left\{(i-1) D_{p}\right\}\right]}{D_{p}} \mid
\end{aligned}
$$

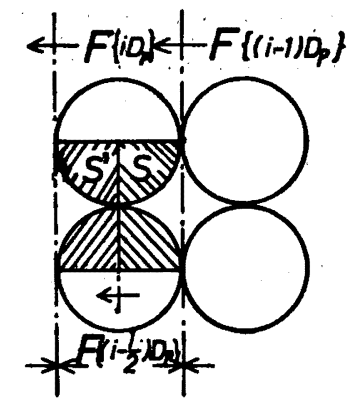

\section{$R_{2 i+1} R_{i j} R_{z_{i-1}} R_{2 i-2}$}

Fig. 2 Radiosity and radiant heat flux

$$
\begin{gathered}
\left\{x-(i-1) D_{p}\right\}+F\left\{(i-1) D_{p}\right\} \\
\left(i-\frac{1}{2}\right) D_{p} \leq x<i D_{p} ; \\
F\{x\}=\frac{2\left[F\left\{i D_{p}\right\}-F\left\{\left(i-\frac{1}{2}\right) D_{p}\right\}\right]}{D_{p}} \\
\left\{x-i D_{p}\right\}+F\left\{i D_{p}\right\} \quad(i=1 \sim n)
\end{gathered}
$$

$i$ 層目の粒子を $2 N$ 等分して $h=D_{p} / 2 N$ とおき，さ らに Eqs.(7)，（8）を用いて Eq.(5) を差分形に变形する と,

$$
(i-1) D_{p} \leq x<\left(i-\frac{1}{2}\right) D_{p} \text {; }
$$$$
x=(i-1) D_{p}+m h, \quad(i=1 ; m=1 \sim N-1, i=2 \sim n \text {; }
$$$$
m=0 \sim N-1 \text { ) }
$$

$$
\begin{aligned}
T_{i, m}= & \frac{1}{2}\left(T_{i, m-1}+T_{i, m+1}\right)+\frac{h^{2}}{k_{a}\left(T_{i, m}\right)} \\
& {\left[k_{a}^{\prime}\left(T_{i, m}\right) \frac{\left(T_{i, m+1}-T_{i, m-1}\right)^{2}}{8 h^{2}}\right.} \\
& \left.-\frac{\left\{R_{2 i-1}-R_{2 i-2}-\phi_{1}\left(R_{2 i+1}-R_{2 i-2}\right)\right\}}{D_{p}}\right]
\end{aligned}
$$

$\left(i-\frac{1}{2}\right) D_{p} \leq x<i D_{p}$

$x=\left(i-\frac{1}{2}\right) D_{p}+m^{\prime} h,\left(i=1 \sim n ; m^{\prime}=0 \sim N-1\right)$

$$
\begin{aligned}
& T_{i, N+m^{\prime}}= \frac{1}{2}\left(T_{i, N+m^{\prime}-1}+T_{i, N+m^{\prime}+1}\right)+\frac{h^{2}}{k_{a}\left(T_{i, N+m^{\prime}}\right)} \\
& {\left[k_{a}\left(T_{i, N+m}\right) \frac{\left(T_{i, N+m^{\prime}-1}-T_{i, N+m^{\prime}+1}\right)^{2}}{8 h^{2}}\right.} \\
&-\left.\frac{\left\{R_{2 i}-R_{2 i+1}-\phi_{1}\left(R_{2 i-2}-R_{2 i+1}\right)\right\}}{D_{p}}\right] \\
& k_{a}{ }^{\prime}=d k_{a} / d T
\end{aligned}
$$

数値計算の手順はつぎのよらであった。まず, 温度分 布の第0近似 $T^{(0)}$ に直線を仮定し，Eq.(6) の連立方程 式より $R^{(0)}$ を求め, この $R^{(0)}$ を用いて Eq.(9)より 第 1 近似 $T^{(1)}$ を求める。以下この手順を繰り返し, $\left|\frac{\left(T^{(\jmath)}-T^{(j-1)}\right)}{T^{(j)}}\right|<10^{-4}$ となった時の $T^{(\jmath)}$ を温度分布 


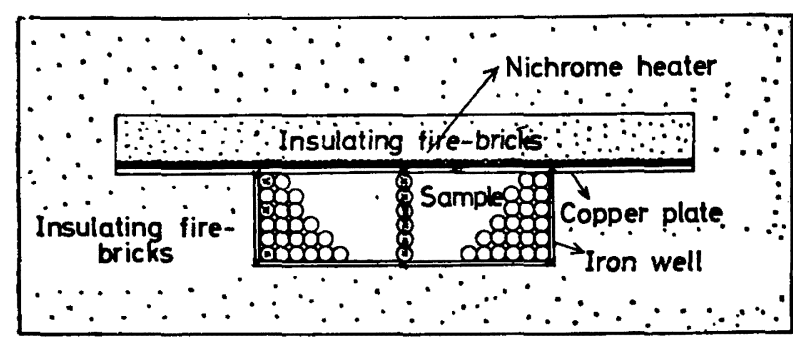

$x$ : Temperature Measurement :Point

Fig. 3 Experimental apparatus
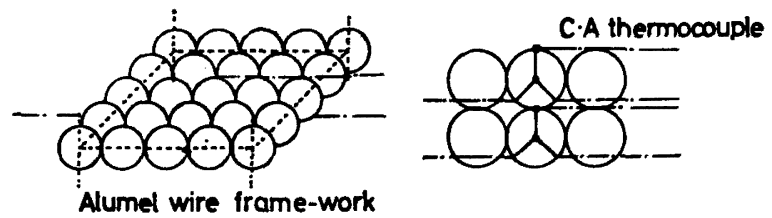

Fig. 4 Detailed temperature measurement points

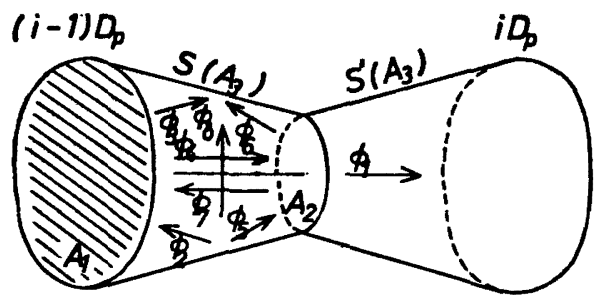

Fig. 5 Angle factor

Tとした。なお，Eq.(6)の程分項の計算には梯形則を 用いまた $N=10 \sim 15$ Kとった。

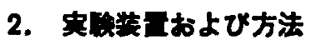

試料として, 平均径 $10 \mathrm{~mm}$ および $15 \mathrm{~mm}$ の 2 㮩粸の 朝鮮カオリン球を用いた。試料球は，朝鲜カオリン粉末 を水で担和し，球に成型後，約 $800^{\circ} \mathrm{C}$ の電気妒で $2 \sim 3$ 時間吰したるのである。

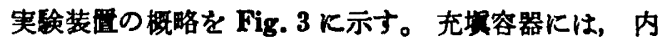
径 $300 \mathrm{~mm}$ (内厚 $3 \mathrm{~mm}$ ), 高さ $60 \mathrm{~mm}(10 \mathrm{~mm}$ 球充塨) および $75 \mathrm{~mm}$ (15 mm 球充埙) の 2 暞類の鉄製円简容

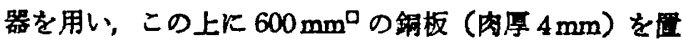

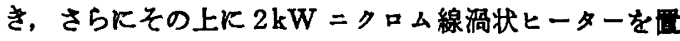
いて加熱した。周围は充分保温し，また定電王装睓付ス ライドトランスによって銅板下表面温度を的一一定にな るように調節した。試料球は可能なかぎり立方配列に充 埧し，とくに中心部では，Fig.4に示すよ5に試料球に $0.1 \mathrm{~mm}$ 径アルメル案線を通して試料球枠組を作りより 正確な立方配列にした。

つぎに温度測定について述べる。温度測定には 0.1 min 径 CA 熱電対とボテンショメーターを用いた。充虽
層内の温度測定位置は，Fig.4亿示すよ5に各 層の中心部試料球中心および表面であった。な おのらに示すよらに低温飞拈ける首内温度分布 が直線性をすつことから，充填屏内の温度測定 位置は確保されていると考えた。また上下壁温 度 (各 3 点), 容器側壁近傍の 試料球中心温度 （3点）る湘定した。リードKよる云導損失を より少なくするため，熱電対は容器半径方向に 引き出した。

前記 2 種類の試料球 について, 上壁温度が $60 \sim 590^{\circ} \mathrm{C}$ の範囲で定常状態における上記各点 の温度を測定した。な护本装監の端効果は，測 定結果から求めた半径方向の温度勾配と軸方向 の温度勾配との 比が $1 / 20$ 以下であり，無視し てすさしつかえないと考えた。

\section{3. 英験結果むよび考寮}

\section{3・1 $k_{*}(T), k_{s}(T)$ および $\phi$ の值}

数值計算飞用いた有効熱云導度 $k_{\mathrm{e}}(T)$ ，見かけ熱云導 度 $k_{a}(T)$ および角関係 $\phi$ の値について述へる。

有効熱云導度 $k_{e}(T)$ 飞は，前報”の輻射を考感した 有奻熱云学度

$k_{e}(T)$

$$
\begin{aligned}
& =k_{q}\left[\frac{1-\varepsilon^{1.3}}{\frac{k_{q}}{k_{s}} \frac{1}{1+\frac{h_{r g} \varepsilon^{1.8} D_{p}}{k_{0}} \frac{k_{q}}{k_{g}\left(1-\varepsilon^{1.3}\right)}}+\frac{1}{\frac{1}{\psi}+\frac{h_{r s} D_{p}}{k_{q}}}}\right. \\
& \left.+\frac{4 h_{r o \varepsilon^{1.8}} D_{p} / k_{q}}{1+\left\{\frac{h_{r \varepsilon^{1.8}} D_{p}}{k_{g}\left(1-\varepsilon^{1.8}\right)}+\frac{1}{\psi}+\frac{h_{r g} D_{p}}{k_{g}}\right\} \frac{k_{g}}{k_{q}}}\right]
\end{aligned}
$$

を用いた。ここで， $k$ （朝鮮カオリン）には線热源法に よって実則した結果より，近似的に

$$
k_{8}=3.4 \times 10^{-4} \times T+0.60
$$

を与え，また $k_{0}$ (空気) には化工便筧の値より近似的に

$$
k_{g}=6.4 \times 10^{-5} \times T+0.003
$$

を与えた。さらに $\phi K$ Kは，国井，Smith ${ }^{2)}$ の線図(㵊䟱 充虽）上り，本実験範囲では $k_{a} / k_{0}$ の值の変化が少ない ので平均値 0.12 を与えた。

つぎに見かけ熱云算度 $k_{a}(T)$ には，上述の $k_{8}(T) に$ おいて輻射依存項を除いたもの，すなわち

$$
k_{a}(T)=\frac{1-\varepsilon^{1.3}}{\frac{1}{k_{\mathrm{a}}}+\frac{\psi}{k_{0}}}
$$

を用い， $k_{t}, k_{q}, \psi$ Kは上述の各値をあてた。

角関係申に成しては，その正確な值を求めるためには 複雑な3次元系を取り报わなければならないが，ここで は近似的に充買周ニニットを Fig. 5 と示すよ5な円錘 台閉空間と仮定し，Appendix 1 K示すよらな方法で 


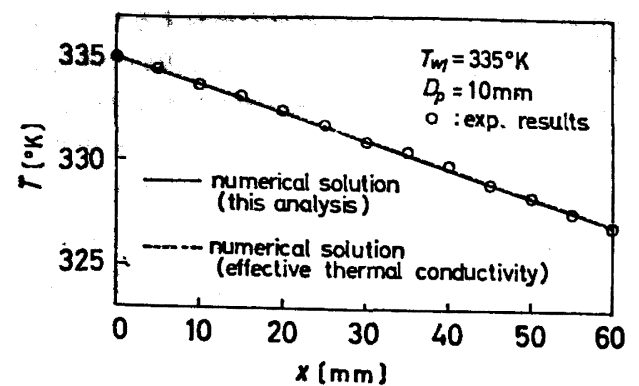

Fig. 6 Temperature distribution in packed bed

$\phi_{1} \sim \phi_{4}$ を算出した。その結果， $\phi_{1}=0.07 ， \phi_{2}=0.70$, $\phi_{3}=0.88$ およ゙ $\phi_{4}=0.12$ であった。また $\phi_{1}$ は充呮層内 の 1 層の透過率であり，別K試作した透過率測定装居に て $10 \mathrm{~mm}$ および $15 \mathrm{~mm}$ 径試料球について $\phi_{1}$ を実湘し たところ，計算値とほぼ同様な值 0.08 を得た。

\section{$3 \cdot 2$ 結果の比校およひ考寀}

Figs. 6 8K $10 \mathrm{~mm}$ 径試料球に対する屏内温度分布 の実験結果と 1.1 および 1.2 Kよろ解析結果との比较を 示す。なお計算にあたって $\varepsilon_{1}=\varepsilon_{2}=0.8, \varepsilon_{p}=0.9$ とした。 これらの図に示した実跧桔果から，上壁温度の上界とと すに，とくに上壁近傍において温度分布の形が勾配が大 きくなる方向へ弯曲し、さらにその影婹か層内深くまで 及んでいることが認められる。本実験籁囲では，1.1の 有効熱云尊度 $k_{s}(T)$ を用いた解析結果は㬏射の寄与の 增加ととるに直線温度分布の上侧へ但るのに対して, 1.2の本モデルによる 解析結果仕実䋡結果と傾向的にか なりよい一政を示している。なお $\varepsilon_{p}=0.9$ として計算を 行なったが，参考として $\varepsilon_{p}=0.8$ とした場合の結果を Fig. 8 に示した。 $\varepsilon_{p}$ の値によって温度分布が若干巽なる か，実験結果の㑯向とは大きくずれていないように思わ れる。

一般に充塂層内の层熱を考える場合，温度分布ととも に熱流束の検討を行なわなければならないか，本研究で

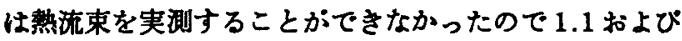
1.2 の解析結果にもとついて繁流束に検討を加えてみ る。1.2の解析結果にもとつく輻射熱流束 $F(x)$ の計算 結果を Figs. 6 8の場合について Fig. 9 K示す。ここで Figs. 8，9 K示した計算結果を用いて，1 例として $T_{w 1}=$ $820^{\circ} \mathrm{K}$ の場合について, 1.1 上り求めた上等の熟流束と

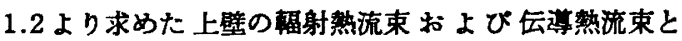
を比較してみる。有効熱云導度に上る熱流束 $-k_{0}(T)$ $\left.\frac{d T}{d x}\right|_{x=0}$ は $480\left[\mathrm{kcal} / \mathrm{m}^{2} \cdot \mathrm{hr}\right]$, 輻射熱流束 $F(0)$ は一 $410\left[\mathrm{kcal} / \mathrm{m}^{2} \cdot \mathrm{hr}\right]$, 伝導熱流束 $-\left.k_{a}(T) \frac{d T}{d x}\right|_{x=0}$ は 875 $\left[\mathrm{kcal} / \mathrm{m}^{2} \cdot \mathrm{hr}\right]$ であり，それぞれの全熱流束 $-k_{e}(T)$ $\left.\frac{d T}{d x}\right|_{x=0}$ と $\left(F(0)-\left.k_{a}(T) \frac{d T}{d x}\right|_{x=0}\right)$ とは注同様の値 であった。なお他の場合について同粎な計算を行なった

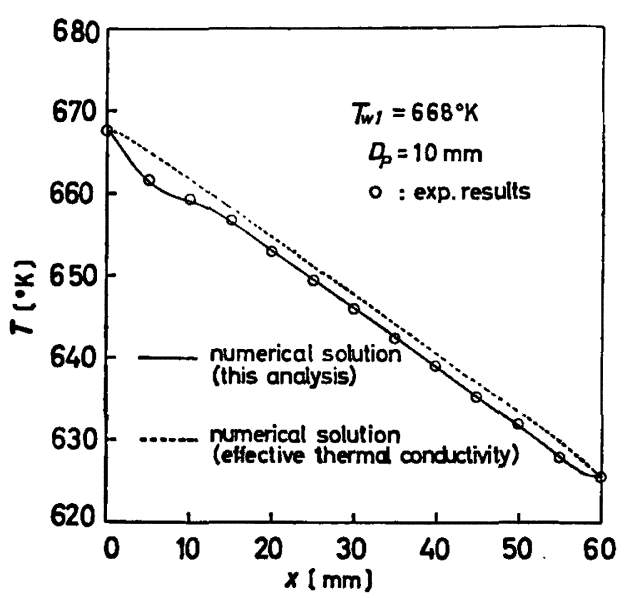

Fig. 7 Temperature distribution in packed bed

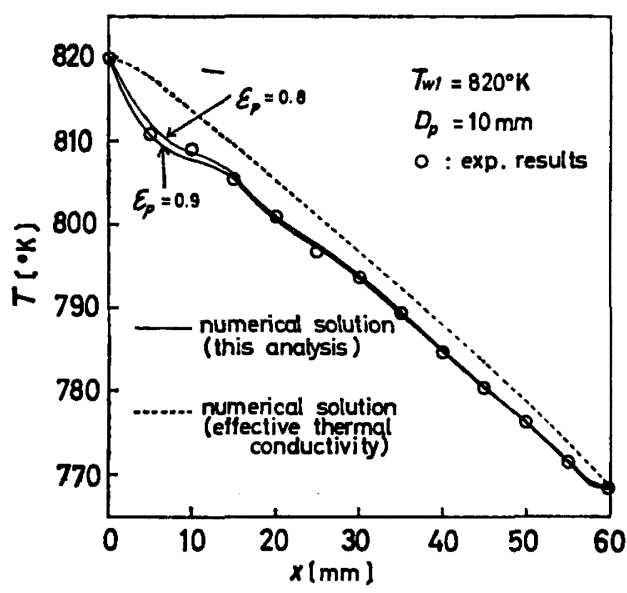

Fig. 8 Temperature distribution in packed bed

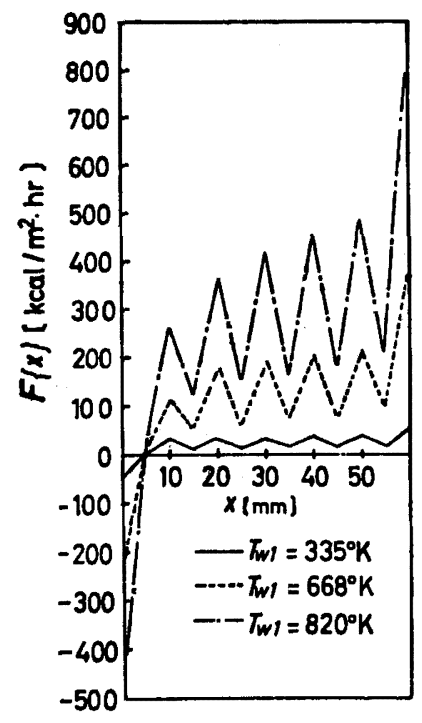

Fig. 9 Radiant heat flux 
ところ，両者の間にはほとんど差異が認められなかっ た。このよ5に，本実験範囲では，全熱流束に関しては 1.1 の解析結果と 1.2 の解析結果との間にははとんど差 異が認められないが, Figs.6 8からわかるように層内 温度分布に関しては1.2の本モデルによる解析の方がよ り妥当であると思われる。

つぎにこのよらな温度分布と上壁温度との成係をさら に詳しく検討するため，輻射熱流束 $F(x)$ と上壁温度と の䦭連をみてみると、Fig. 9からわかるよらК上壁温度 の上昇とともに輻射熱流束 $F(x)$ の絶対值が大きくな り，さらに1周目においては負の大きな値となる。これ は上壁温度の上早ととるに上壁の射出年および粒子の射 出吾が增加し，とくに1居目では粒子の射出量と上壁の 射出量の反射を主成分とする 負方向の Radiosity が正方 向の Radiosity より大きくなるためである。なお輻射熟 流束 $F(x)$ は粒子の射出率 $\varepsilon_{p}$ ，旺の射出率 $\varepsilon_{1}, \varepsilon_{2}$ などに よって変化するが,これらに対する詳細な恰討は今後実 倹的検討とあわせて行な5必要があると思われる。

粒子径の変化は，本実験筑用では温度分布の形にあま り影零を与えず， $15 \mathrm{~mm}$ 径試料球の実験結果 計算結 果とす $10 \mathrm{~mm}$ 径試料球の 結果とほほ同様なむのであっ た。

以上のことから，本実験筑囲では1.2の本モデルによ 万層内温度分布の解析が一義的には本実検秸果に対して 妥当性をるつことがわかったが，今後さらに熟流束に园 して理詥的，実験的に検討する必要があり，また気体内 および粒子内云導の局所性についてす検討する必要があ ると思われる。

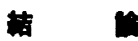

静止充垻凰（ガス，平行平板系）内の伝熱において，

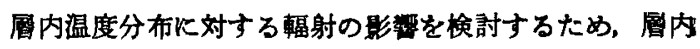
温度分布を 1.1 の既往の有效熱云咅度を用いた埸合およ び1.2の新たに輻射に壁の影稫を考虎した場合につい て，それぞれ数值的に解析し，両者の結果をカオリン球 を用いた実験結果と対応させて比較検討した。その結 果，本実験籍囲では，层熱量汇関しては 1.1 の解析結果 と 1.2 の解析絬果との間にはほとんど差異が㤎められな かったが，屏内温度分布に威しては 1.2 の本モデルによ る解析結果が実験結果とかなり良好な㑯向的一致を示 し，本モデルKよる解析がり妥当であることがかかっ た。また上壁温度の上㫒とともに，とくに上壁近傍にお いて温度分布の形が勾配が大きくなる方向へ弯曲するこ とが認められた。

\section{Appendix 1}

Fig. 5 に示した円釷台閏空间系において，各角威係の間には,

$$
\begin{array}{ll}
\phi_{3}+\phi_{1}=1 & \phi_{3} A_{1}=\phi_{2} A_{3} \\
\phi_{6}+\phi_{7}=1 & \phi_{4} A_{1}=\phi_{7} A_{2} \\
\phi_{2}+\phi_{5}+\phi_{3}=1 & \phi_{5} A_{3}=\phi_{6} A_{2}
\end{array}
$$

の上ラな咸係がある。ここと,

$$
\begin{aligned}
& A_{1}=D_{p}^{2} \quad A_{2}=\left(1-\frac{\pi}{4}\right) D_{p}^{2} \\
& A_{3}=\frac{\sqrt{(4-\pi) \pi}+2 \pi-6}{2(\sqrt{(4-\pi) \pi}+3 \pi-8)} \pi D_{p}^{2}
\end{aligned}
$$

である。

角网保 7 㑑に対して式が 6 個あるので，独立に 1 個の角夙保 を求めなければならないるそこで，好を Jakob2》の提出した同 蚰平行円板に対广る式上り求め, $\phi_{4}=0.12$ とした。したがって 前式上り

$$
\begin{array}{lll}
\phi_{2}=0.70, & \phi_{3}=0.88, & \phi_{5}=0.07, \\
\phi_{6}=0.45, & \phi_{7}=0.55, & \phi_{8}=0.23
\end{array}
$$

また,

$$
\phi_{1}=\phi_{4} \times \phi_{7}=0.07
$$

\section{Nomenclature}
$D_{p}=$ diameter of particle
$F \quad=$ radiant heat flux
$k_{a}$ = apparent thermal conductivity due to conduction and convection $\quad\left[\mathrm{kcal} / \mathrm{m} \cdot \mathrm{hr} \cdot{ }^{\circ} \mathrm{C}\right]$
$k_{e}=$ effective thermal conductivity due to conduction, convection and radiation
$\left[\mathrm{kcal} / \mathrm{m} \cdot \mathrm{hr} \cdot{ }^{\circ} \mathrm{C}\right.$ ]
$k_{0} \quad=$ thermal conductivity of gas
[kcal/m.hr $\cdot{ }^{\circ} \mathrm{C}$ ]
$k_{\text {s }}=$ thermal conductivity of particle $\left[\mathrm{kcal} / \mathrm{m} \cdot \mathrm{hr} \cdot{ }^{\circ} \mathrm{C}\right.$ ]
$L \quad=$ height of packed bed
[m]
$R$ = radiosity
$T$ = absolute temperature
$x=$ coordinate in direction of heat flow
[kcal $\left./ \mathrm{m}^{2} \cdot \mathrm{hr}\right]$
[ $\left.{ }^{\circ} \mathrm{K}\right]$
[m]

- = void fraction

$[-]$

$c_{1}, c_{2}, c_{p}=$ emissivity of upper wall, lower wall and particle

- = Stefan-Boltzmann constant $\left[\mathrm{kcal} / \mathrm{m}^{2} \cdot \mathrm{hr} \cdot{ }^{\circ} \mathrm{K} \triangleleft\right]$

$\phi i=$ angle factor

$[-]$

effective thickness of fluid film filling

$\phi \quad=\frac{\text { in void with respect to thermal conduction in it }}{}$ diemeter of particle 


\title{
Literature cited
}

1) Sugiyamz, S. and M. Fujitsu: Kagaku Kōgaku, 24, 12(1960)

2) Kunii, D. and J. M. Smith: A. I. Ch. E. Journal, B, 71(1960)
3) Jakob, M.: "Heat Transfer” 2 nd ed., John Wiley and Sons, Inc. (1957)

\section{虽媒の二元細孔構造を考虑したクロマト反応器周波数応答*}

\author{
熊 沢 英 博**.森 田 德 義** \\ 名古座大学工学部 化学工学科
}

\section{传旦}

著者らは先に，クロマト反応器の周波数応答を均一細 孔モデルK基ついて濖析し、エチレンの水秦化反応につ

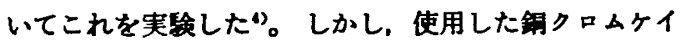

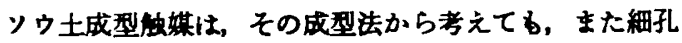
分布曲線を测定した結果からる，多元細孔椿造を持って いる。粒子を成型した媒の細孔模造は通常，マク口 孔とミクロ孔が直列に連結していると考えられ。そのよ

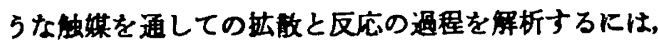
二元緗孔带造を考虑した数学的モデルが必要である。

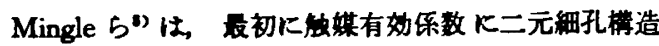
の概念を算入した。すなかち，非等温 1 次非可逆反応の 場合、粒子内の細孔分布を考虑したミク只有效倸数を 使ってマクロ有效保数を数值解析した。その後，Car-

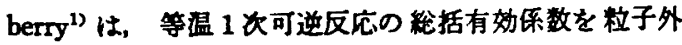

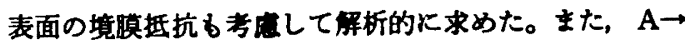
$\mathrm{B} \rightarrow \mathrm{C}$ なる 1-1 次逐㰠庆の中間生成物 B の選択性を， ミク口，マク口有圽俰数，反応速度定数扰上び外部物留 移動俰数によって角析的飞表现した2”。若尾らは等温 1 次可道反応の有奻保数を random pore モデルに基ふい

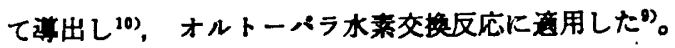
小宮山，井上") は， $\mathrm{A} \rightarrow \mathrm{B} \rightarrow \mathrm{C}$ 故万逐次反応の B 選択

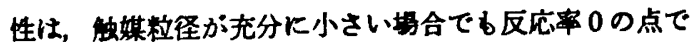

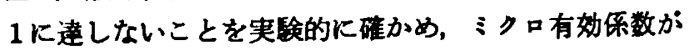
重要な影篦を与えることを示した。

以上住，ミクロ，マク口有好俰数が総括有奻俰数户選

- <Frequency Reaponse in Chromatographic Reactor in View of Bimodal Pore Structure of Catalyst Pellet>

Received on January 7, 1971

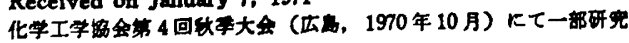
劳哀

** Hidehiro Kumazawa and Noriyouhi Morita (Dept. of Chem. Eng, Faculty of Eng, Nagoya Univ, Nagoya, Japan)
\end{abstract}

択性に与える影雷を定常反応法に上り検討した研究であ って, 二元細孔モデル特有の現象をとらえて均一細孔モ デルと比校した研究は，小宮山，井上 ${ }^{6,7)}$ が上記の逐次 反応の中間生成物の瀷択性について行なった研究以外は 見当らない。しかし，著者らが先に示したよらに”，均 一細孔モデルにおいて有奻保数が1に近い坦合です，高 周波のゲインに粒子内拡散の影繁が現われることを考萀 すれば，二元細孔モデルにおいてミクロ，マクロ有效係 数が 1 に近くても，高周波のゲインを揤定すれば，ミク 口孔およびマクロ孔払散の影䉕がともと現われるので， 二元細孔モデルと均一細孔モデルの選別ができる。本報 においては，均一細孔モデルと二元細孔モデルに対する 周波数伝達閔数を比較して，特徽的な相连のあることを 示し，前報と同一の反応和の周波数応答に対する触媒粒 径の影霍についての実験を行ない，その結果が二元細孔 モデルによって始めて説明できることを示す。

\section{1. 二元淍れモテルによる用波数层这闺数の特性}

流体本体中の拡散の影害および境膜物筫移動抵抗を無 視し，反応物はまずマク口孔を厸散し，つぎにミク口孔 を抎散して、ミクロ孔内表面に吸着して反応するとす る。また，反応速度性粒子内反応物の局所港度火n 次， $R_{\Lambda}=k_{n}{ }^{\prime} K_{\Lambda}{ }^{n} C_{\Lambda i}{ }^{n}$ ，で表わされるとする。触媒有奻 保数が汪とんど1と考えられるときたは，反応物 Aの 浱度の正弦波摄動の入力と出力の間の周波数伝遠関数は つきの式で与えられるう。

$$
G(i \omega)=\exp \left[-i \omega \tau-\frac{9 n \theta_{n}}{h_{60}{ }^{2} \beta^{2}} \int_{0}^{1}\left(\hat{Y}_{1}+i \hat{Y}_{2}\right) d x\right]
$$

Eq.(1) Кおいて， $\beta \rightarrow 0 ， \varepsilon_{a} \rightarrow 0$ とすれば，均一細孔モ デルに対する周波数伝達閔数"となる。

$$
G(i \omega)=\exp \left[-i \omega \tau-\frac{3 n \theta_{n}}{h_{0}^{2}} \int_{0}^{1}\left(Y_{1}+i Y_{2}\right) d x\right]
$$


気液平衡式のパラメー夕決定法-Wilson, NRTL, Heil 式 について (宮原是中・佐渡友秀夫, 化学工学, 35, 1347 1353 (1971))

無限稀釈溶液の活量係数から Wilson, NRTL, Heil の式のハ ラメータを簡単に決定する方法を提案し，解と 2 組以上の解の存在 与る籁用を $\left(\gamma_{1}^{0}, \gamma_{2}^{0}\right),\left(A_{12}, A_{21}\right),\left(T_{12}, T_{21}\right),\left(\tau_{12}, \tau_{21}\right)$ 面 に図示し 2 組以上の解が得られたとさどの解を用いるが使う補助 的図をむ併せて提案した。本法を正に偏倚した Acetone-Methanol 采拉上び負仁偏倚した Acetone-Chloroform 系汇適用し满 足な結果を得ることを確認した。

\section{静止充増層内における伝熱——層内温度分布におよばす輻射} の影響——(西村 誠・稲葉由大・架谷昌信・杉山幸男，化 学工学, 35, 1354 1359 (1971))

静止充填層 (ガス, 平行平板系) 内の伝熱に批いて，層内温度分 布に対する輻射の影響を検討するため，層内温度分布を（i）既往の 有効熱公導度を用いた場合，(ii) 新たに輻射に壁の影響を考虑した 昜合について，それぞれ数值的に解析し，両者の結果をカオリン球 $\left(D_{p}=10 \mathrm{~mm}, 15 \mathrm{~mm}\right)$ を用いた実験結果（加熱壁温 $60 \sim 590^{\circ} \mathrm{C}$ ) と対応させて比挍検討した。その結果，本実験範囲では，伝熱量に 関しては（i）の解析結果と（ii）の解析結果との間にはほとんど差 淇が認められなかったが，層内温度分布に関しては（ii）の本モゔ ルKよる解析結果が実験結果とかなり良好な傾向的一致を示し，本 モデルによる解析がより妥当であることがわかった。また上壁温度 の上昇とともに，とくに上壁近傍に和いて温度分布の形が勾配が大 きくなる方向へ雪曲することが認められた。

触媒の二元細孔構造を考慮したクロマト反応器 周 波数応答 （熊沢英博 ·森田德義, 化学工学, 35，1359～1364 (1971)) 触蝶の細孔構造に均一細孔モデルを適用したときと, 二元細孔モ デルを適用したときの周波数応签には本質的な相違のあることを指 摘し，粒径の異なる触媒によるエチレン水素化反応の周波数応答実 伢の結果が二元細孔モデルによって始めて説明しらることを示し た。さらに, 周波数层達関数から, 反応状態下でのミク口孔, マク 口孔有效拓散保数を決定する方法を示して，これによって得られる 結果は，実測した紐孔分布曲線からら推算される值とよく一致した。

光化学反応装置の設計因子一光吸収速度 一 ( 城塚 正 . 西海英雄, 化学工学, 35, 1364 1372 (1971) ?

光反応では濃度変化と光ェネルギーの吸収が相互作用を及湆し合 ら。午のため基礎式は複雜となり光化学反応器を設計するには簡単 でない。そこで光吸収速度の数学的取り报いを単純化した 3 種の近 似式をたてた。1つの近似式を検討した結果光学厚みが 5 以下で妵 反応中の濃度変化による光強度の変化は無視できることがわかっ た。残りの近似式は低収率域に適用できるがその適用範用について も考察した。実験值と光四収速度項を近似しない理論值はよく一致 Lた。
移動層内粒子の半径方向主応力および速度分布に対する塑性 力学的考察 (高橋洋志・柳井 弘, 化学工学, 35, 1372 1379 (1971))

移動層内粒子の半径方向主応力は, フララグフロー領域（速度の一栏 な領域)の先端付近からら次第に大きくなり，壁面上で最大值を示し， また軸方向速度は壁近傍で急钽な遅れ勾配をもって变化することが 実測された。一方，応力と速度の場に塑性理論を適用して検討した 結果，層中心部と壁面上の忘力のそれぞれを予測することができ， さらに速度分布が不連統になる場所の存在することが見いだされ， 実験結果学定性的に説明できることがわかった。

回分横型㩭拌槽によるガス吸収速度の研究（安藤公二・原

弘・遠藤一夫, 化学丁学, 35, 1379 1383 (1971))

幾何学的に相似な 3 秏の横型摫汼槽を用い,タービン羽根によっ

て罟拌し，覀硫酸ソーダ水溶液に上る酸素ガス吸収速度を測定し て，以下の結果をえた。

1）槽内液の飛散が著しい $A_{1}$ 状態に扎いては，総括吸収容量係数 はフルード数に比例する。

2）実用的に重要な $A_{1}$ 状態につき，総括吸収容量係数 $K_{G} \cdot a$ と 液単位体皘当りの所要動力 $P_{v}$ との関係は

$K_{G} \cdot a=K P_{v} \quad: \varepsilon=0.4 \sim 0.6, \quad D_{t}=10.6 \sim 18.4 \mathrm{~cm}$ $K=6.2 \times 10^{-9}$ (酸素一覀硫酸ノ一ダ水溶液系)

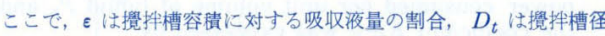
である。

《技術報告〉

試作回転式スクラバーの装置性能（松野儀三・平岡正勝，化 学工学, 35, 1384 1390 (1971))

多孔板, 回転翼各 3 段よりなる試作回転式スクラパーを考案, 開 発した。実験結果によると，液ガス此の変化にかかからず効率が㤝 添一定で, 安定度の高い装置であった。この装置の総括捕集効率を 求めるために, 装置を構成する回転翼等による捕集実験を行ない, その結果からサイクロン効果俰数, 泡洙層効果俰数, 翼効果保数を 定義しこれらの効果保数を用いて複雑な機構からなる装置の総括 捕集效率を概算する一方法を試みた。
<寄 書>

厚み計の一利用法——電解槽中の陽極板の厚み測定——(酒 井信之・田口洋治, 化学工学, 35，1391 1393 (1971))

故射線を用いた厚み計は被測定物に接触することなく，また破烄 ナることなく，厚さを測定できることが特街である。このため既に 多くの工程検查などで実用化されている。本研究では $S_{r}-90(Y$ 90)の $\beta$-を線源とし，透過型厚久計の原理を报張して，電解槽中 の陽極板(銅板)の厚みの連続測定を試みた。炎の結果，電解俯の厚 みが入っているにもかかわらず, 陽極板の厚さで 50〜 $500 \mathrm{mg} / \mathrm{cm}^{2}$ の範用で測定可能であることを見いだした。

泡沫の管内流饥について 森島直正・吉田折夫・大引常弘 化学工学, 35, 1393 1395 (1971))

表面活性剤溶液によって作られた泡洙群の水平管内の流れの圧力 損失と速度分布を測定した。その結果，泡洙の流れは非ニュートン 流体の擬塑性流体として报えることがわかり，から活性剤の濃度に よって指数が変化した。さらに管摩摖保数は, 擬逆性流体のレイノ ルズ数を用いることにより、ニュートン流体の層流域にお。的る $f$ $R e$ の関係と一致することが見いだされた。

超音波を照射した液体中における球の抗力（原＼cjkstart弘・遠滕 一夫, 化学工学, 35, 1395〜1397 (1971)

脱気した水，水了×水溶液に超音波を照射し，その5 ちにある珛 に加わる抗力を測定した。实験的関係はつぎのよ5に表わされる。 $F=3 \cdot 10^{-3} a \cdot \omega^{3 / 2} \cdot d^{2}$

2 成分系精留塔動特性の非対称性（水野博之・西村義行 ・ 松 原正一，化学工学，35，1397 1400 (1971)

2 成分系精留塔の動特性を数倠計算火上って研究し, 新しい形式 の非对称性を見いだした。加藤が指摘した非対称性は還流比のスン ップ変化の方向関するるのであったのに対して，筆者らが見いた した非対称性は還流比を基準值からずらす場合に比して基準值にも

どす場合の方が著しく応签が遅いといらすのである。 
<Short Communications >

Thickness Gage for Anode Plate in an Electrolytic Bath, N. Sakai and Y. Taguchi (Niigata Univ.)

Kagaku Kōgaku, 35, 1391 1393 (1971)

Thickness gage using radiation rays has its characteristic merits, i.e., no contact with the materials, no destruction of the materials, etc. These gage are widely used now in the various fields having these merits.

In the present report the principle of thickness gage (transmission type) was extended to and applied to the continuous measurement plate in an electivity was about $10 \mathrm{mCi}$. As a result, it was recognized that $50 \sim 500 \mathrm{mg} / \mathrm{cm}^{2}$ was the measurable range of this gage for anode plate (copper plate) in spite of involving the thickness of electrolyte.

On the Flow of Foam in a Pipe, N. Morishima, T. Yoshida and T. Oubiki (Osaka City Univ.)

Kagaku Kögaku, 35, 1393 1395 (1971)

The pressure drop and velocity profile due to the flow of foam, which was generated by the bubbling section of a horizontal pipe. It was confirmed that the flow of foam could be treated as pseudo-plastic fluid of non-Newtonian and the exponent in formula of pseudo-plastic flow depended on the concentration of surfactant in solution. The relation between Reynolds number, a characteristic formula of pseudoplastic fluid, and friction factor was the same as that
of the laminer flow region in Newtonian fluid.

Force on a Sphere in Liquid Irradiated by Ultrasonic Wave, H. Hara (Muroran Inst. of Tech.) and $\mathrm{K}$. Endoh (Hokkaidō Univ.)

Kagaku Kōgaku, 35, 1395 1397 (1971)

Experiments were performed on force on a sphere suspended in liquid by ultrasonic plane wave. Liquids used were water and water-cornsyrup solution without dissolved gas.

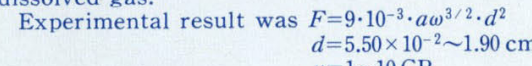

$\mu=1 \sim 10 \mathrm{CP}$

Where $d$ is the diameter of sphere, $\mu$ viscosity of liquid, $F$ force on a sphere suspended in liquid by ultrasonic plane wave ticle displacement.

On Asymmetric Properties of Binary Distillation Column Dynamies, H. Mizuno, Y. Nishimura and M. Matsubara (Nagoya Univ.)

Kagaku Kōgaku, 35, 1394 1400 (1971)

The dynamic behavior of a binary distillation column was numerically investigated and a new type of asymmetric property was then observed. The asymmertry which was pointed out by Kato was that being concerned with the direction of stepwise change in reflux ratio. The new type of asymmetry is as follows. the response of composition in each plate is far more sluggish for the recovery of reflux ratio to from the normal value.
Discussion on the Distribution of Radial Stress and Vertical Velocity of Particles in a Moving Bed by Plasticity Theory, H. Takahashi and $\mathrm{H}$. Yanai (Muroran Inst. of Tech.)

Kagaku Kögaku, 35, 1372 1379 (1971)

It was recognized experimentally in a vertical moving bed that a radial normal stress acting on an element in the bed began to incease in ilu fly with radial distance from near the edge of plug flow reveloped into a maximum value on the wall, and that the radial distribution of vertical velocity showed a great reduction in velocity only near the wall although a velocity was gradually reduced apart form the wall.

On the other hand, the radial normal stresses in the plug flow region and on the wall and radial dis tribution of vertical velocity were respectively predicted on the basis of plasticity theory in which stress and velocity characteristics coinside, and compared with experimentally determined characteristics. As a result of it, it was concluded that each radial normal stresses computed by theory reasonably agreed with experimental ones, and that the existance of discontinity of vertical velocity at a position in mentally determined velocity field could be interpretted as discontinuity.

Studies on the Rate of Gas-Absorption in Batch Horizontal Stirred Vessels, K. Andou, H. Hara Muroran Inst. of Tech.) and K. Endoh (Hokkaidō Univ

Kagaku Kōgaku, 35, 1379 1383 (1971)

Studies were made on the transfer rate of oxygen into sodium sulphite solution in the horizontal stirred izsed $D_{t}=10.6 \sim 18.4 \mathrm{~cm}$ in diameter, agitated by turbine type impellers. Results obtained were as follows: 1) In the state $A_{1}$, in which the liquid is splashed violently by the impeller in the vessel, over-all volumetric absorption coefficient is obtained to be linear with Froude Number.

2) It is most effective for absorption to operate in the $A_{1}$ state. In this state, the correlation between per unit volume of liquid $P_{v}$ and the coefficient $K_{G} \cdot a$ was expressed by

$$
\begin{aligned}
& \begin{aligned}
K_{G} \cdot \mathrm{a}=K P_{v},: & \varepsilon=0.4 \sim 0.6, \quad D_{t}=10.6 \sim 18.4 \\
& K=6.2 \times 10^{-9} \quad \text { (oxygen-sodium }
\end{aligned} \\
& \text { te solution) }
\end{aligned}
$$

where, $s$ is the ratio of the volume of liquid to

that of vessel.

\section{$<$ Technical Report>}

Perforicance on a Rotational Vane Type Scrubber, Y. Matsuno (Kyushu Inst. of Tech.) and M. Hiraoka (Kyoto Univ.)

Kagaku Kōgaku, 35, 1384 1390 (1971)

A rotational vane type scrubber which was buil with three units of a perforated plate and a rotational vane was tested. It showed a constant and good ratio. In connection with the above experiment, the experiments using each unit, i.e a vane, a rotational disk and a perforated plate were carried out. From these experimental results and theoretical view points, an idea of the effect-coefficient was introduced for each unit. Semi-theoretical analysis was tried by using these effect-coefficients.
Procedure to Evaluate the Wilson, NRTL and Heil Parameters, K. Miyahara and H. Sadotomo (Mitsui Toatsu Chemicals, Inc.

Kagaku Kögaku, 35, 1347 1353 (1971)

The authors have proposed a simple procedure by which, utilizing the activity coefficients in the infiHeil parameters can be evaluated without difficulty. The possibility has been shown that multiple solutions exist if the activity coefficients in the infinitely dilute binary solution are used. Also shown are the regions of multiple solutions of the Wilson, NRTL and Heil equations on the $\left(\gamma_{1}^{0}, \gamma_{2}^{0}\right),\left(A_{12}, A_{21}\right),\left(T_{12}\right.$, $\left.T_{21}\right)$ and $\left(\tau_{12}, \tau_{21}\right)$ plane, and graphs which aid to select the appropriate solution among multiple solutions. By the method described above, the authors evaluated the parameters for the acetone

Heat Transfer in Static Packed Beds - The Effects of Radiation on the Temperature Distributions-_, M. Nishimura, S. Sugiyama, Y. Inaba and M. Hasatani (Nagoya Univ.)

Kagaku Kögaku, 35, 1354 1359 (1971)

The effects of radiation on the temperature distributions in the static packed beds was studied. The temperature distributions were analysed numerically for two cases in applying (i) the effective thermal conductivity and (ii) the radiant heat flux involving the wall effects, and the two results were compared with the experimental results $(10 \mathrm{~mm}$ and $15 \mathrm{~mm} \mathrm{ka}$ olin balls, heating temperature ranging from 60 to $590^{\circ} \mathrm{C}$. Consequently, under the present experimental conditis the heat transfer rates obtained from (i) and (ii) but with respect to the temperature distribution the results of (i) showed fairly good similarity to the experimental results and the model applying (i) was more adequate, and that the temperature gradients, especially in the neighbourhood of the heating plate, became steeper with increasing the heating plate temperature.

Frequency Response in Chromatographic Reactor in View of Bimodal Pore Structure of Catalyst Pellet, H. Kumazawa and N. Morita (Nagoya Univ.) Kagaku Kögaku, 35, 1359 1364 (1971)

A characteristic difference in frequency transfer functions for chromatographic reactor obtained for quency resere over different sizes of catalyst gave results which could be explained well only by the bimodal pore model. A method to estimate effective diffusion coefficients in micro and macropores under reaction conditions was also presented. The coefficients obtained by the method agreed fairly with estimated values from pore size distribution curve of the catalyst.

Design Factors of Photochemical Reactors - Rate of Absorption of Light Energy_-, T. Shirotsuka and $\mathrm{H}$. Nishiumi (Waseda Univ.)

Kagaku Kōgaku, 35, 1364 1372 (1971)

The rate of absorption of light energy greatly affects the rate of photochemical reactions. As it is too com plicated to solve general design equations exactly, three simpler approximations are set up. Results by one of the approximations show that the change of light intensity during the reaction is negligible if optical thickness $\tau \leqq 5$. The condition on which the other approximations can be applicable are described. Ex perimental data are in agreement with calculated values. 